\title{
Manifestasi Klinis dan Fungsi Ventrikel pada Kardiomiopati Dilatasi
}

\author{
Sri Endah Rahayuningsih \\ Departemen Ilmu Kesehatan Anak RS Dr. Hasan Sadikin Fakultas Kedokteran Universitas Padjadjaran, \\ Bandung
}

\begin{abstract}
Latar belakang. Kardiomiopati dilatasi merupakan kelainan miokardium yang memiliki angka harapan hidup 5 tahun yang semakin rendah dengan manifestasi klinis bervariasi. Fungsi kedua fungsi ventrikel dapat dinilai melalui ekokardiografi..

Tujuan. Mengetahui hubungan manifestasi klinis dengan fungsi ventrikel pada kardiomiopati dilatasi Metode. Penelitian deskriptif analitik dengan data berdasarkan rekam medis dan data ekokardiografi pasien kardiomiopati dilatasi di Bagian Ilmu Kesehatan Anak RS Dr. Hasan Sadikin Bandung periode Januari 2008-Desember 2012. Penilaian fungsi jantung melalui ekokardiografi dengan penentuan fraksi ejeksi (ventrikel kiri) dan penilaian tricuspid annular plane systolic excursion (TAPSE) (ventrikel kiri). Hubungan korelasi dianalisis dengan tes Spearman.

Hasil. Didapatkan 43 anak dengan diagnosis kardiomiopati dilatasi. Keseluruhan pasien semua bayi/anak dengan kardiomiopati dilatasi datang dengan gagal jantung dan menunjukkan penurunan fungsi ventrikel kiri fraksi ejeksi 32,02\% (15-50) dan terdapat penurunan fungsi ventrikel kanan, yaitu TAPSE 15,97 mm (12-21). Korelasi manifestasi klinis dengan fungsi ventrikel kiri dan kanan mendapatkan riwayat ISPA berulang tidak berhubungan dengan penurunan TAPSE. Riwayat keluarga, riwayat miokarditis sebelumnya, gangguan pertumbuhan, dan emboli sistemik menunjukkan arah korelasi negatif terhadap fraksi ejeksi berturut-turut $(r=-0,71 ; p=0,649 ; r=-0,26, p=0,827 ; r=-0,118, p=0,45 ; r=-0,64 ; p=0,681)$. Emboli paru menunjukkan arah korelasi negatif terhadap TAPSE ( $r=0,166 ; p=0,288)$.

Kesimpulan. Kardiomiopati dilatasi menyebabkan penurunan fungsi ventrikel kiri dan kanan, serta menimbulkan manifestasi klinis yang berat dan prognosis yang jelek. Sari Pediatri 2015;16(6):403-8.
\end{abstract}

Kata kunci: kardiomiopati dilatasi, fungsi ventrikel, fraksi ejeksi, TAPSE

\footnotetext{
Alamat korespondensi:

DR. dr. Sri Endah Rahayuningsih Sp.A(K). Bagian Ilmu Kesehatan Anak Fakultas Kedokteran Universitas Padjadjaran/RS Hasan Sadikin Bandung. Jl. Pasteur 38 Bandung 40161 Telp/Fax. 022-2034426. E-mail: endah.perkani@gmail.com
}

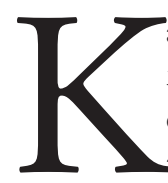
ardiomiopati dilatasi adalah kelainan miokardium yang ditandai dengan dilatasi dan kelainan fungsi sistolik ventrikel kiri kedua ventrikel tanpa penyakit arter koroner, kelainan katup, penyakit perikardium, dan penyakit jantung bawaan. Angka harapan hidup pasien kardiomiopati dilatasi adalah $79 \%$ pada 1 tahun dan $61 \%$ pada 5 tahun. ${ }^{1-3}$ 
Etiologi kardiomiopati dilatasi pada sebagian besar kasus tidak diketahui, sedangkan sisanya disebabkan karena miokarditis dan kelainan neuromuskular. ${ }^{1,4}$ Faktor risiko kematian pasien kardiomiopati dilatasi, yaitu disfungsi ventrikel kiri, gagal jantung kongestif, emboli trombus, dan aritmia. ${ }^{3}$

Manifestasi klinis kardiomiopati dilatasi sangat bervariasi dan bergantung pada usia pasien serta beratnya disfungsi ventrikel. Hal tersebut meliputi gangguan pertumbuhan, edema paru, hipertensi pulmonal, dan emboli pada sistemik maupun pulmonal. ${ }^{5,6}$ Sebagian besar kasus menunjukkan manifestasi klinis gagal jantung yaitu peningkatan gejala tekanan vena pulmonalis dan atau curah jantung yang rendah. ${ }^{1}$ Ekokardiografi merupakan pemeriksaan noninvasif dan dapat digunakan untuk mengukur fungsi ventrikel kiri maupun kanan yang menurun pada kardiomiopati dilatasi. ${ }^{2}$

Tujuan penelitian ini untuk mengetahui hubungan manifestasi klinis dengan fungsi ventrikel pada kardiomiopati dilatasi.

\section{Metode}

Penelitian ini merupakan penelitian deskriptif analitik. Data diambil berdasarkan rekam medis dan data ekokardiografi pasien kardiomiopati dilatasi di Bagian Ilmu Kesehatan Anak RS Dr. Hasan Sadikin Bandung periodik Januari 2008-Desember 2012. Kriteria inklusi adalah usia $<14$ tahun dan diagnosis kardiomiopati dilatasi berdasarkan ICD 10. Kriteria eksklusi adalah penyakit metabolik, muscular dystrophy, dan penyakit jantung bawaan.

Data rekam medis, meliputi nama, jenis kelamin, tanggal lahir, manifestasi klinis (gangguan pertumbuhan, infeksi saluran pernapasan akut/ISPA berulang, gagal jantung, emboli paru, dan strok), foto toraks, elektrokardiografi, dan pemeriksaan penunjang lain seperti CT-Scan kepala. Gangguan pertumbuhan diketahui dengan menggunakan WHO Child Growth Standard 2006 berdasarkan antropomentri berat badan dan usia diklasifikasikan menjadi normal, underweight, and severely underweight. Pada penelitian ini gizi normal=gizi baik, underweight=gizi kurang dan severely underweight=gizi buruk. ${ }^{7}$ Klasifikasi gagal jantung berdasarkan sistem skoring gagal jantung pada bayi menurut Modifikasi Ross, yaitu gagal jantung ringan, sedang, dan berat. ${ }^{8}$ Infeksi saluran napas akut (ISPA) berulang apabila terdapat riwayat ISPA lebih dari 4-6 kali per tahun. ${ }^{9}$ Endokarditis infeksi ditegakkan berdasarkan kriteria Duke. ${ }^{10,11}$ Data elektrokardiografi (EKG) meliputi gangguan irama jantung dan hipertrofi ruang jantung.

Data ekokardiografi meliputi hasil rekaman ekokardiografi dan intepretasinya yang disimpan di Instalasi Pelayanan Jantung dalam bentuk file digital. Hasil intepretasi ekokardiografi, meliputi fungsi ventrikel kiri, fungsi ventrikel kanan, pulmonal hipertensi, emboli atau trombus intrakardiak, dan efusi perikardium. Fungsi ventrikel kiri ditentukan dengan pengukuran fraksi ejeksi memakai ekokardiografi $M$-mode pada potongan sumbu panjang parasternal, kursor diletakkan pada ujung katup mitral dengan

Fraksi ejeksi (FE) = DVKI-AD-DVKI-AS x 100\% DVKI-AD

\section{Keterangan:}

- DVKI-AD adalah dimensi ventrikel kiri pada saat akhir diastol

- DVKI-AS adalah dimensi ventrikel kiri pada saat akhir sistol

monitor EKG. Parameter yang dinilai adalah,

Fungsi ventrikel kanan ditentukan dengan mengukur tricuspid annular plane systolic excursion (TAPSE), dilakukan dari pandangan apikal 4 ruang. Dengan menggunakan $M$-mode kursor diletakkan di anulus trikuspid sejajar dengan gerakan anulus tersebut, kemudian diukur jarak (distance) titik anulus trikuspid pada sistol dan diastol..$^{12,13}$

Hipertensi pulmonal diukur dengan pemeriksaan color Doppler sampel volume (diatur pada lebar 1,5 $\mathrm{mm}$ ) diletakkan. di antara ujung daun katup trikuspid pada pandangan apikal empat ruang. Kesejajaran gelombang ultrasonik terhadap arus darah diatur dengan memanipulasi transduser sampai diperoleh kecepatan spektral yang tertinggi dan suara yang jernih. Setelah regurgitasi trikuspid terlihat, diukur kecepatan aliran (V) dan perbedaan tekanan sistol antara atrium dan ventrikel kanan dapat diperhitungkan dengan rumus $\mathrm{P}=4 \mathrm{~V}^{2}$. Selanjutnya, tekanan ventrikel kanan dan arteri pulmonalis juga dapat diperkirakan dengan menambah hasil perhitungan di atas dengan perkiraan tekanan atrium kanan $(10 \mathrm{mmHg}){ }^{12,13}$

Ekokardiografi dilakukan oleh seorang konsul- 
tan kardiologi anak dengan menggunakan alat ekokardiografi Vivid 7 General Electric. Transduser yang digunakan adalah 2,4 dan $5 \mathrm{MHz}$.

\section{Hasil}

Selama kurun waktu penelitian ditemukan 43 anak dengan kardiomiopati dilatasi. Kardiomiopati dilatasi yang disertai sindrom adalah 6 kasus dan hanya 2 bayi yang mempunyai riwayat keluarga dengan kardiomiopati dilatasi (Tabel 1).

Semua bayi/anak dengan kardiomiopati dilatasi datang dengan gagal jantung. Selain gagal jantung, manifestasi klinis yang sering ditemukan yaitu ISPA berulang dan gangguan pertumbuhan. Manifestasi klinis yang paling jarang ditemukan adalah emboli paru dan endokarditis infektif (Tabel 2).

Tabel 3 menunjukkan bahwa sebagian besar kardiomiopati dilatasi menunjukkan kasus hipertrofi ventrikel
Tabel 3. Elektrokardiografi pada kardiomiopati dilatasi

\begin{tabular}{ll}
\hline Irama sinus & \\
\hline Bradikardia sinus & 5 \\
Takikardia sinus & 27 \\
Normal & 5 \\
Gangguan irama & \\
$\quad$ Takikardia supraventrikular & 4 \\
$\quad$ Blok atrioventrikular total & 2 \\
Gangguan ruang jantung (\%) & \\
$\quad$ Hipertrofi ventrikel kiri & $28(65)$ \\
$\quad$ Hipertrofi biventrikular & $15(35)$ \\
\hline
\end{tabular}

(65\%) dan 15 kasus (35\%) hipertrofi biventrikular (hipertrofi ventrikel kiri dan kanan). (Tabel 3).

Semua subyek penelitian menunjukkan penurunan fungsi ventrikel kiri fraksi ejeksi 32,02\% (15-50) dan terdapat penurunan fungsi ventrikel kanan yaitu,TAPSE $15,97 \mathrm{~mm}$ (12-21). Semua bayi/

Tabel 1. Karakteristik data

\begin{tabular}{lc}
\hline Data & $\mathrm{N}=43$ \\
\hline Usia (bulan) & $81(1-168)$ \\
Jenis kelamin & \\
$\quad$ Laki laki & 26 \\
$\quad$ Perempuan & 17 \\
Sindrom & \\
$\quad$ Down & 3 \\
Hurler & 1 \\
Marfan & 1 \\
Status gizi (\%) & \\
$\quad$ Baik & $18(42)$ \\
$\quad$ Kurang & $12(28)$ \\
$\quad$ Buruk & $13(30)$ \\
Riwayat keluarga dengan kardiomiopati dilatasi & 2 \\
Riwayat miokarditis sebelumnya & 5 \\
\hline
\end{tabular}

Tabel 2. Manifestasi klinis

\begin{tabular}{lc}
\hline Manifestasi klinis & $\mathrm{N}=43$ \\
\hline Gagal jantung & 43 \\
Gangguan pertumbuhan (\%) & $25(58)$ \\
ISPA berulang (\%) & $38(88)$ \\
Endokarditis infektif (\%) & $3(6)$ \\
Emboli paru (\%) & $3(6)$ \\
Emboli sistemik (\%) & $11(6)$ \\
\hline
\end{tabular}

Tabel 4. Ekokardiografi pada kardiomiopati dilatasi

\begin{tabular}{lc}
\hline Fraksi ejeksi & $32,02 \%(15-50)$ \\
TAPSE & $15,97 \mathrm{~mm}(12-21)$ \\
Vegetasi intrakardiak (N) & 5 \\
Efusi perikardial (N) & 23 \\
Trombus intra kardiak (N) & 3 \\
Tekanan arteri pulmonalis (N) & $65 \mathrm{mmHg}(30-95)$ \\
\hline
\end{tabular}


anak dengan kardiomiopati dilatasi menunjukkan peningkatan tekanan a. pulmonalis yaitu $65 \mathrm{mmHg}$ (30-95) (Tabel 4).

Terdapat korelasi sindrom, riwayat keluarga kardiomiopati, riwayat miokarditis sebelumnya, gangguan pertumbuhan, endokarditis infektif, emboli paru, dan emboli sitemik dengan fraksi ejeksi dan TAPSE. Riwayat ISPA berulang tidak berhubungan dengan penurunan TAPSE. Riwayat keluarga, riwayat miokarditis sebelumnya, gangguan pertumbuhan, dan emboli sistemik menunjukkan arah korelasi negatif terhadap fraksi ejeksi. Emboli paru menunjukkan arah korelasi negatif terhadap TAPSE.
Miokarditis yang disebabkan oleh virus didasari oleh reaksi imunologis cell-mediated. Reaksi tersebut ditandai infiltrat selular, degenerasi sel dan nekrosis, serta fibrosis. Miokarditis oleh virus juga dapat menjadi kronik. Inflamasi kronik ini memengaruhi respons imun, termasuk aktivasi limfosit T. Limfosit sitotoksik, sel natural killer (NK), dan replikasi virus menyebabkan kerusakan fungsi miosit tanpa sitolisis yang jelas. Protein virus juga dapat membagi epitop antigenik dengan sel inang sehingga menyebabkan reaksi autoimun. Sitokin seperti tumor necrosis factor- $\alpha$ (TNF $\alpha$ ) dan interleukin-1(IL1) menyebabkan perubahan pada respons imun. Inflamasi yang

Tabel 5. Korelasi manifestasi klinis dengan fungsi ventrikel kiri dan kanan

\begin{tabular}{lcccc}
\hline \multirow{2}{*}{ Variabel } & \multicolumn{2}{c}{ Fungsi ventrikel kiri } & \multicolumn{2}{c}{ Fungsi ventrikel kanan } \\
\cline { 2 - 5 } & Nilai korelasi Spearman & $\mathrm{p}$ & Nilai korelasi Spearman & $\mathrm{p}$ \\
\hline Sindrom & 0,64 & 0,681 & 0,168 & 0,283 \\
Riwayat keluarga dengan kardiomiopati & $-0,71$ & 0,649 & 0,319 & 0,37 \\
Riwayat miokarditis sebelumnya & $-0,26$ & 0,867 & 0,467 & 0,02 \\
Riwayat ISPA berulang & 0,26 & 0,867 & 0,524 & 0,000 \\
Gangguan pertumbuhan & $-0,118$ & 0,451 & 0,113 & 0,471 \\
Endokarditis infektif & 0,22 & 0,888 & 0,166 & 0,288 \\
Emboli paru & 0,22 & 0,888 & 0,166 & 0,288 \\
Emboli sistemik & $-0,64$ & 0,681 & $-0,168$ & 0,283 \\
\hline
\end{tabular}

\section{Pembahasan}

Kardiomiopati dilatasi merupakan kelainan kardiomiopati yang paling sering ditemukan. Penyebab tersering adalah idiopatik (60\%), sedangkan penyebab lain meliputi kardiomiopati familial dan miokarditis. ${ }^{10}$ Pada penelitian ini ditemukan 2 kasus dengan riwayat kardiomiopati dilatasi familial. Hal tersebut berbeda dengan penelitian sebelumnya yang menyatakan kardiomiopati dilatasi familial terjadi pada $20 \%-$ $48 \%$ kasus. ${ }^{14}$ Kardiomiopati dilatasi familial diduga disebabkan oleh mutasi gen. Penelitian sebelumnya menunjukkan terdapat 40 lokus kromosom yang berhubungan dengan kardiomiopati dilatasi familial. Mutasi gen akan menyebabkan gangguan pembentukan protein sarkomer, $\mathrm{Ca}^{2+}$-handling, reseptor kanal ion positif, cytoskeletal, nuclear, faktor transkripsi, dan protease yang saling berinteraksi sehingga menyebabkan disfungsi sistol ventrikel kiri. ${ }^{15}$

Kami menemukan 5 pasien kardiomiopati dilatasi yang mempunyai riwayat miokarditis sebelumnya. berkepanjangan pada akhirnya dapat menyebabkan kardiomiopati dilatasi. ${ }^{16,17}$

Kardiomiopati dilatasi dapat disertai dengan kelainan neuromuskular, inborn errors of metabolism, dan sindrom malformasi, ${ }^{10}$ tetapi patomekanisme keterlibatan kelainan kardiovaskular termasuk kardiomiopati dilatasi pada kelainan tersebut belum jelas. Kami menemukan kardiomiopati dilatasi dengan sindrom Down, Hurler, dan Marfan, sedangkan kelainan neuromuskular, inborn errors of metabolism, dan sindrom malformasi yang lain tidak dianalisis.

Semua bayi/anak dengan kardiomiopati dilatasi datang dengan gagal jantung. Kardiomiopati dilatasi adalah suatu kelainan otot jantung sehingga terjadi penurunan fungsi ventrikel kiri dan kanan. Penurunan fungsi ventrikel kiri menyebabkan jantung tidak dapat memompa secara efektif dan mengakibatkan bendungan pada paru (edema paru). ${ }^{18}$ Penurunan fungsi ventrikel kiri mengakibatkan gejala low cardiac output yang dapat muncul sebagai takikardia sinus pada EKG,${ }^{18}$ seperti yang terlihat pada penelitian ini. 
Pada penelitian ini ditemukan pasien kardiomiopati dilatasi dengan gangguan irama, yaitu bradikardia sinus, AV blok total, dan takikardia supraventrikular. Hal tersebut merupakan salah satu gejala miokarditis. Penyebab lain kardiomiopati dilatasi adalah infeksi virus, bakteri, dan protozoa. ${ }^{10,18}$

Kardiomiopati dilatasi dapat disebabkan oleh gangguan gizi, seperti defisiensi karnitin, beri-beri, dan kwasiorkor. ${ }^{10,18}$ Kami hanya menemukan pasien dengan gizi buruk, tipe marasmic, tidak ditemukan pasien kwasiorkor dan beri-beri, sedangkan untuk defisiensi karnitin, tidak dievaluasi karena tidak dilakukan pemeriksaan kadar karnitin.

Pada kardiomiopati dilatasi terjadi penurunan fungsi ventrikel kiri sehingga terjadi edema paru yang menyebabkan respiratory distress. Edema paru akan menyebabkan peningkatan tekanan a. pulmonalis yang pada akhirnya akan meningkatkan tekanan ventrikel sehingga terjadi dilatasi ventrikel kanan. $^{10,18}$ Hal tersebut sesuai dengan temuan EKG yang menunjukkan pada semua pasien terdapat hipertrofi ventrikel kiri dan sebagian pasien hipertrofi biventrikular (hipertrofi ventrikel kiri dan kanan). Penurunan fungsi ventrikel kiri juga ditunjukkan oleh hasil pemeriksaan ekokardiografi, yaitu penurunan fraksi ejeksi 32,02\% (15-50)\%. Ditunjukkan juga penurunan fungsi ventrikel kanan, walaupun penelitian tentang penurunan fungsi ventrikel kanan belum banyak dilakukan. Penelitian yang dilakukan oleh Groner $\mathrm{dkk}^{19}$ menunjukkan TAPSE pada anak dengan kardiomiopati dilatasi adalah $8,58 \pm 5,54 \mathrm{~mm}$, sedangkan pada penelitian ini $15,97 \mathrm{~mm}$.

Hipertensi pulmonal didefinisikan sebagai peningkatan tekanan arteri pulmonal rata-rata $\geq 25 \mathrm{mmHg} .{ }^{10}$ Hipertensi pulmonal merupakan kelainan pembuluh darah paru yang berat dan progresif, ditandai peningkatan resistensi vaskular paru yang dapat menyebabkan gagal jantung kanan. Hipertensi pulmonal pada kardiomiopati disebabkan fungsi ventrikel kiri yang menurun menyebabkan edema paru yang akan meningkatkan tekanan a. pulmonalis. Pada bayi dan anak dengan tekanan a. pulmonalis yang meningkat, baik yang disebabkan oleh penyakit jantung bawaan maupun kardiomiopati dilatasi akan mengalami ISPA berulang. ${ }^{18}$

Penurunan fungsi ventrikel kiri dan kanan pada kardiomiopati dilatasi menyebabkan gangguan aliran darah sistemik dan pulmonal yang kemudian berakibat stasis pada ventrikel kanan dan kiri dan dapat membentuk trombus. Pembentukan trombus yang disertai bakteri patogen akan terjadi vegetasi yang dapat mengikuti aliran darah dan menimbulkan komplikasi endokarditis infektif; selain itu trombus dapat lepas dari dinding ventrikel dan akan mengikuti sirkulasi darah yang akan menyebabkan emboli pada organ-organ tubuh. ${ }^{10,18}$ Pada penelitian ini ditemukan pasien kardiomiopati dilatasi dengan trombus intrakardiak, emboli paru, emboli sistemik, dan vegetasi intrakardiak.

Penelitian ini menunjukkan terdapat korelasi manifestasi klinis dan sindrom, riwayat keluarga dengan kardiomiopati, serta riwayat miokarditis sebelumnya terhadap fungsi ventrikel kiri dan fungsi ventrikel kanan. Hanya riwayat ISPA berulangyang tidak berhubungan dengan penurunan TAPSE. Walaupun ISPA berulang berhubungan dengan terjadinya dilatasi ventrikel kanan, tetapi pengukuran TAPSE mempunyai banyak kelemahan. Hingga saat ini, pengukuran fungsi ventrikel kanan pada kardiomopati dilatasi masih menunjukkan hasil yang kontroversi.

\section{Kesimpulan}

Penelitian ini adalah kardiomiopati dilatasi merupakan penyakit pada otot jantung yang menyebabkan penurunan fungsi ventrikel kiri dan kanan, serta menimbulkan manifestasi klinis yang berat dan prognosis yang jelek. Sayangnya sampai saat ini tidak ada pencegahan untuk kardiomiopati dilatasi. Patomekanisme kardiomiopati dilatasi sampai saat ini belum jelas.

\section{Daftar pustaka}

1. Towbin JA, Lowe AM, Colan SD, Sleeper LA, Orav EJ, Clunie S, dkk. Incidence, causes, and outcomes of dilated cardiomyopathy in children. JAMA 2006;296:186776.

2. Wilkinson JD, Landy DC, Colan SD, Towbin JA, Sleeper LA, Orav EJ, dkk. The pediatric cardiomyopathy registry and heart failure: key results from the first 15 years. Heart Fail Clin 2010;6:401-13.

3. Elkilany GE, Al-Qbandi MA, Sayed KA, Kabbash I. Dilated cardiomyopathy in children and adults: what is new? Sci World J 2008;8:762-75.

4. Taylor MR, Carniel E, Mestroni L. Cardiomyopathy, 
familial dilated. Orphanet J Rare Dis. 2006;1-27.

5. Chung B, Wong V. Pediatric stroke among Hong Kong Chinese subjects. Pediatrics 2004;114:e206-12.

6. Hamilton RM, Azevedo ER. Sudden cardiac death in dilated cardiomyopathies. Pacing Clin Electro Physiol 2009;32S:32-40.

7. World Health Organization. The WHO child growth standards 2006. Diunduh 14 Januari 2010. Didapat dari: http;//www.who.int/childgrowth/.

8. Ross RD. The Ross classification for heart failure in children after 25 years: a review and an age-stratified revision. Pediatr Cardiol 2012:1-6.

9. Wilar R, Wantania JM. Beberapa faktor yang berhubungan dengan episode infeksi saluran pernapasan akut pada anak denganpenyakit jantung bawaan. Sari Pediatri 2006;8:154-8.

10. Park MK. Pediatric cardiology for practitioners. Edisi ke-5. Philadelphia: Mosby; 2008.

11. Wilson W, Taubert KA, Gewitz M, Lockhart PB, Baddour LM, Levison M, dkk. Prevention of infective endocarditis: guidelines from The American Heart Association: a guideline from the American Heart Association Rheumatic Fever, Endocarditis, and Kawasaki Disease Committee, Council on Cardiovascular Disease in the Young, and the Council on Clinical Cardiology, Council on Cardiovascular Surgery and Anesthesia, and the Quality of Care and Outcomes Research Interdisciplinary Working Group. Circulation 2007; 116;1736-54.

12. Mertens LL, Rigby ML, Horowitz ES, Anderson
RH. Cross sectional echocardiographic and Doppler imaging. Dalam: Anderson RH, Baker EJ, Penny D, Redington AN, Rigby ML, Wernovsky G, penyunting. Pediatric cardiology. Edisi ke-3. Philadelphia: Churchill Livingstone;2010.h.1020-5.

13. Lai WW, Geva T, Shirali GS, Frommelt PC, Humes RA, Brook MM, dkk. Guidelines and standards for performance of a pediatric echocardiogram: a report from the Task Force of the Pediatric Council of the American Society of Echocardiography. J Am Soc Echocardiogr 2006;19:1413-30.

14. Taylor MR, Carniel E, Mestroni L. Cardiomyopathyfamilial dilated. Orphanet J Rare Dis 2006;13:1-27.

15. Fatkin D, Otway R, Richmond Z. Genetics of dilated cardiomyopathy. Heart Fail Clin 2010;6:129-40.

16. Uhl TL. Viral myocarditis in children. Crit Care Nurse. 2008;28:42-63.

17. Kaski JP, Aelliott P.Cardiomyopathies. Dalam: Anderson RH, Baker EJ, Penny D, Redington AN, Rigby ML, Wernovsky G, penyunting. Pediatric cardiology. Edisi ke3. Philadelphia: Churchill Livingstone; 2010.h.1020-5.

18. Olson TM, Hoffman TM, Chan DP. Dilated congestive cardiomyopathy. Dalam: Allen HD, Gutgesell HP, Clark EB, Driscoll DJ, penyunting. Moss and Adam's heart disease in infants, children, and adolescents. Edisi ke-7. Philadelphia: William \& Wilkins;2008.h.1195-206.

19. Groner A, Yau J, Lytrivi ID, Ko HH, Nielsen JC, Parness IA. The role of right ventricular function in paediatric idiopathic dilated cardiomyopathy. Cardiol Young 2012;1-7.(Epub ahead of print) 